\title{
Biosphere reserves in the mountains of the world and their standing after 40 years of UNESCO's MAB Programme
}

\author{
Sigrun Lange
}

\section{Abstract}

Since 1976, 564 biosphere reserves have been established all over the world; almost two thirds of them are located in mountain areas. They contribute to biodiversity conservation in fragile ecosystems and come up with regionally adapted solutions for a sustainable development of the respective regions.

However, there is still a gap between vision and reality. Many of them do not fulfil the UNESCO criteria defined in the Statutory Framework and exist merely as paper parks. In celebration of the $40^{\text {th }}$ anniversary of UNESCO's MAB Programme, good as well as critical examples of mountain biosphere reserves were collected to highlight the important role they play as sites for international scientific collaboration, biodiversity conservation and sustainable use of natural resources. The findings of almost 50 international authors have been gathered in the publication Biosphere Reserves in the Mountains of the World - Excellence in the Clouds? published by the Austrian Academy of Sciences in February 2011. Some of the results are summarized and presented in this article.

\section{Biosphere reserves in mountain areas}

Exactly 40 years ago, in 1971, the Man and the Biosphere (MAB) Programme was launched by UNESCO as an international research cooperation programme on the interactions between man and the environment. Five years later, the first biosphere reserves (BRs) were established as the programme's main line of action, amongst them for example the mountain areas of Arasbaran BR (Iran), Babia Gora BR (Poland), Beinn Eighe BR (Scotland), or Olympic BR (USA). Since then, the MAB community has grown into a global network of 564 biosphere reserves in 109 countries (UNESCO 2011). Almost two thirds of all BRs registered in the World Database on Protected Areas (WDPA - The most recent version of the WDPA includes a total of 514 BRs, i.e. only $91 \%$ of the 564 BRs internationally recognized by UNESCO) are located in mountain areas. The mountains of South America, Greenland, North Africa and Central and Western Europe are fairly well represented within the World Network of Biosphere Reserves (Rodríguez-Rodríguez \& Bomhard 2011). In contrast, only few BRs exist in the Alps (two in the Swiss, three in the Austrian, one in the Slovenian, one in the German, and none in the Italian Alps) and not a single one is located in the Scandinavian mountains (Norway, Sweden, or Finland). The only Swedish mountain BR, Lake Torne Area, was withdrawn from the UNESCO list in June 2010 as it did not fulfil the criteria of the Statutory Framework (Borowski \& Munteanu 2011).

As reflected by the vision expressed in the Madrid Action Plan (UNESCO 2008, p.8), the World Network of Biosphere Reserves (WNBR) consists of a dynamic and interactive network of sites of excellence. It fosters harmonious integration of people and nature for sustainable development through participatory dialogue, knowledge sharing, poverty

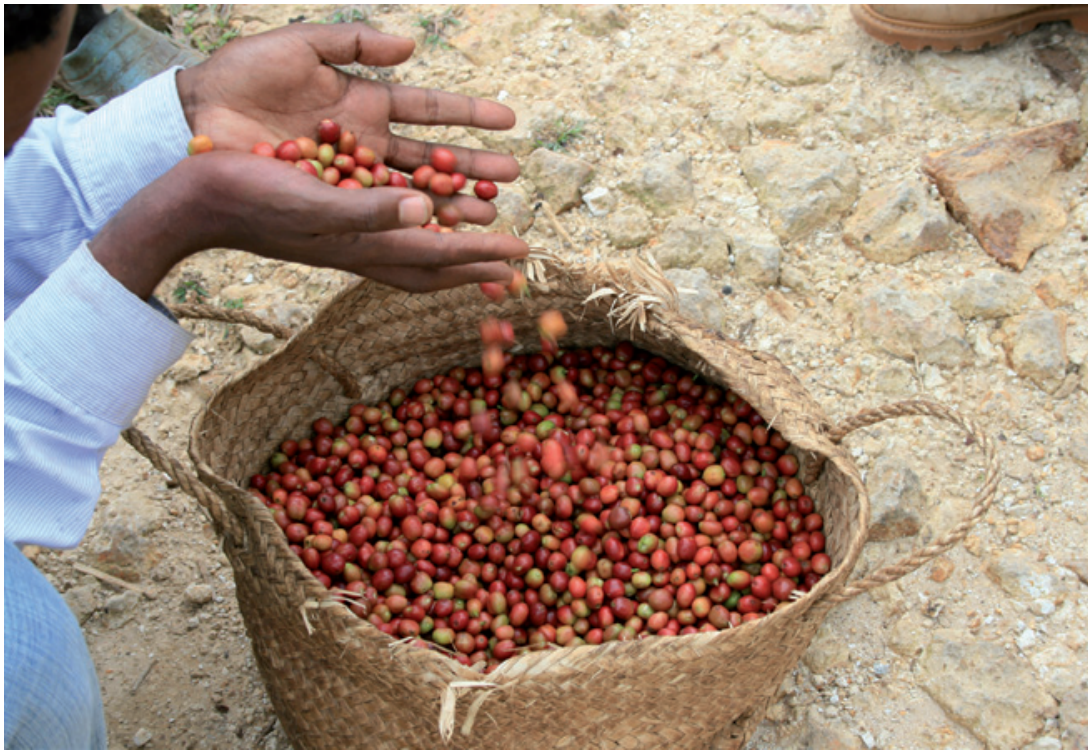

The coffee beans collected in the coffee forests in Kafa Biosphere Reserve (BR) in Ethiopia are exported to German-speaking countries. (C) Jan Schormann

reduction and improvement to buman well-being, respect for cultural values and society's ability to cope with change, thus contributing to the UN Millennium Development Goals. Accordingly, the WNBR is one of the main international tools which facilitate the design and implementation of sustainable development approaches in a wide array of contexts. Implementing UNESCO's MAB concept in an ideal manner is quite a challenging - maybe a little over-ambitious task, but good practice examples show that participatory approaches can make a difference.

\section{Towards the involvement of local people}

Holding a participatory dialogue with local stakeholders is increasingly taken for granted in the development of biosphere reserves. The example of Nanda 


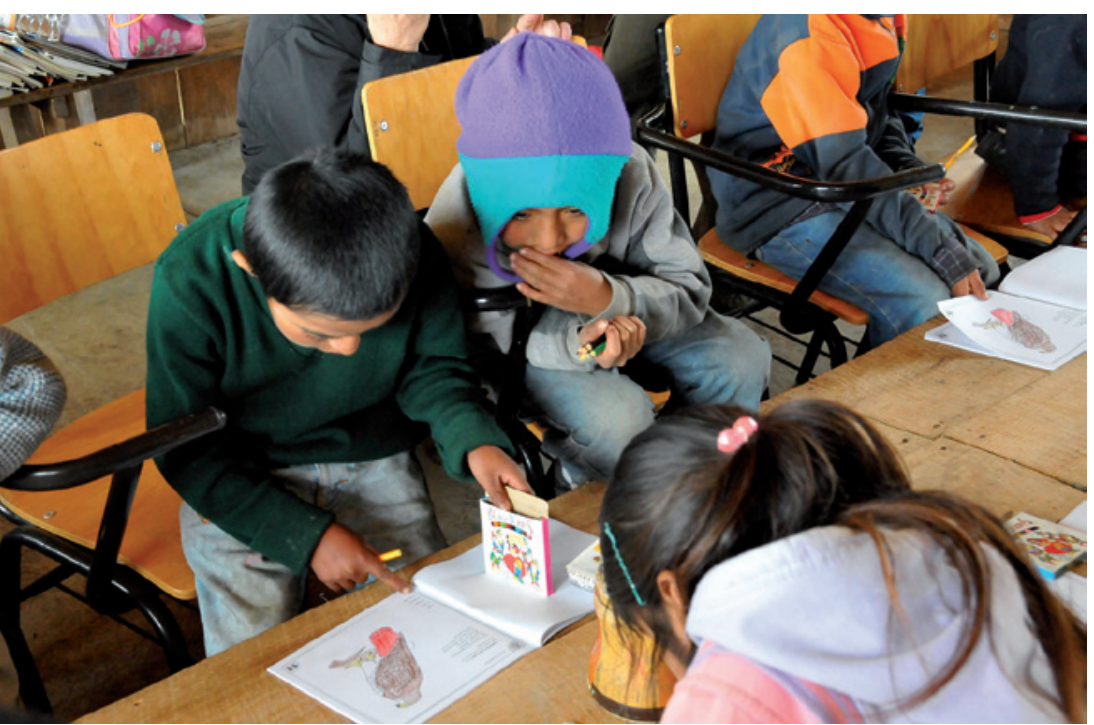

Environmental education in Sierra Gorda BR in Mexico. (C) Roberto Pedraza

Devi BR (India), however, shows that it was not always like this.

Nanda Devi $(7817 \mathrm{~m})$ is the second highest mountain in the Indian Himalayas. It forms the summit of a vast glacial basin ringed by high peaks (Bosak 2008). The interior of this hardly accessible ring is known as the Nanda Devi Sanctuary. Until the 1960s, only some indigenous Bhotiya families inhabited the Nanda Devi area. They made a living mainly from bartering wheat, rice and buckwheat with salt and wool from Tibetans in the North. In summer, they grazed their animals in the sanctuary and collected medicinal plants. Their living conditions began to change in the 1970s, when mountaineering on the Nanda Devi became popular. The Bhotiya people gained additional income from working as porters and guides for expeditions (Saxena et al. 2011). However, with the growing number of mountaineers coming to the mountain area, the impact on the environment became ever more apparent. As a consequence, in 1982, the Nanda Devi Sanctuary was declared a national park - to the detriment of the Bhotiya people. The area was closed to all human activities, including mountaineering and grazing, which meant that the traditional grazing areas became off limits and the Bhotiya also lost the income from tourism. The designation of Nanda Devi Biosphere Reserve in 1988 further increased the area under conservation management. A buffer zone, including village lands, was added and restrictions were imposed on grazing as well as on gathering firewood and nontimber forest products, threatening the livelihood of the Bhotiya people. The top-down policies of the management and inappropriate compensation measures turned the Bhotiya against the protected area (Bosak 2008). They stood up for community-based ecotourism activities in the whole BR and finally succeeded, in 2003: the core zone was reopened for tourism with restrictions on visitor numbers. The income from entrance and overnight fees is now shared between the government and the locals and only locals can be em- ployed as guides and porters. However, the Bhotiya people are still insufficiently involved in the planning, decision-making and monitoring of the ecotourism activities in the area. The task for the future will be to close the gap between vision and reality of the UNESCO concept in this area. Because it "should be kept in mind that conservation and sustainable utilisation of natural resources are centuries-old inherent dimensions of indigenous culture and livelihood, while policy interventions related to conservation and tourism did not emerge in India until the beginning of the 20 th century" (Saxena et al. 2011, p. 79).

\section{New forms of governance}

In the Sierra Gorda mountain range (Mexico), local people do not only get revenues from their BR, they are even involved in its ongoing management. The Sierra Gorda BR, created in 1997, is an exceptional example of a UNESCO site which is co-managed by the national government (CONANP - National Commission of Natural Protected Areas) and the Sierra Gorda Ecological Group (GESGIAP), a local NGO strongly rooted in the region. The people from the Sierra depend largely on subsistence farming and forestry. When GESGIAP was founded in 1987 by local citizens, the Sierra Gorda mountain region was facing many environmental problems (Progreso Network 2011). After initially being engaged in environmental education and reforestation, GESGIAP developed a management plan in 1999 for the newly established $\mathrm{BR}$ in the region and afterwards managed to obtain approval from the Global Environment Facility (GEF) for the implementation of a big biodiversity conservation project which made it possible to accomplish all 167 lines of action envisaged in the management plan (Pedraza 2011). Since then, about 18000 students in 172 schools and 110 communities in the five municipalities of the BR have been involved in environmental education activities; 1500 people have been trained in workshops offered at the Earth Centre. In addition, 110 local and two regional solid waste collection centres have been installed. In 2003, a payment system for ecological services was established in more than 25000 hectares of privately owned forests. This measure not only increased the income of several land owners but also reduced the forest fragmentation by $24 \%$ (Progreso Network 2011). In general, the bottom-up development of the protected area and the strong involvement of local land owners and user groups can be seen as key element for effective nature conservation, especially in countries with insufficient environmental budgets - and for an appropriate management of Sierra Gorda BR in particular (Pedraza 2011). According to a survey by Bertzky (2009), a civil servant in the Mexican government summarized the success of Sierra Gorda BR in one sentence: "The state of conservation of the Sierra Gorda is much better than I would have been able to imagine". 


\section{Ideal Tools for Developing countries}

In general, development cooperation aims at reducing poverty. In this context it is clear that nature should not be protected from people, rather it is to be preserved by using natural resources wisely in cooperation with local people (Dittrich \& Mack 2005). Balancing conservation with sustainable use is exactly what the concept of UNESCO's MAB Programme aims at. This makes BRs ideal tools for developing countries, such as Ethiopia, which is one of the poorest and least developed countries in the world. In 2010, its Human Development Index was valued at 0.328 , putting the country in $157^{\text {th }}$ place of 169 countries (HDI 2010). As part of the East Afromontane Biodiversity Hotspot (one of 34 biodiversity hotspots worldwide defined by Conservation International (Biodiversity Hotspots 2007)), the Ethiopian Highlands are home to a rich diversity of plants and animals - but also to about $90 \%$ of the country's population (EFAP 1994). As a result of population pressure and poor cultivation methods, the highland ecosystems are already highly degraded. Erosion is a severe threat all over the country. Inadequate planning and coordination between the agricultural and natural-resources sectors contribute further to the degradation of land in Ethiopia. The UNESCO concept calls on the persons in charge to encourage research, monitoring and environmental education and to facilitate the cooperation of all stakeholders and sectors concerned towards sustainable development of the region. Through careful planning, BRs can provide alternative means of income generation such as ecotourism and marketing of non-timber (forest) products, thus decreasing a local community's dependence on agriculture (Nune 2011).

In June 2010, the first two BRs have been nominated in the Afromontane coffee forests of south-western Ethiopia, Yayu and Kafa BRs. The Ethiopian Ministry of Science \& Technology, UNESCO's Cluster Office in Ethiopia and NABU, a Germany based NGO, signed an official commitment to jointly designate further BRs in the country. Baseline studies will be conducted for three potential new sites (Bender-Kaphengst 2011), amongst them the Lake Tana area.

\section{Testing a sustainable lifestyle}

As the example of Großes Walsertal BR (Austria) shows, the UNESCO concept not only helps to reconcile poverty reduction with a sustainable use of natural resources, it may also stimulate a lifestyle which is gentle on resources in industrialized societies. Generally it is well known that the consumption of resources increases with growing economic prosperity of the respective society. A dramatic demonstration of this are the carbon dioxide emissions per capita, differing considerably for instance between the USA (17.7 metric tons per person) and Bangladesh (0.4 metric tons)(International Energy Statistics for 2009). The

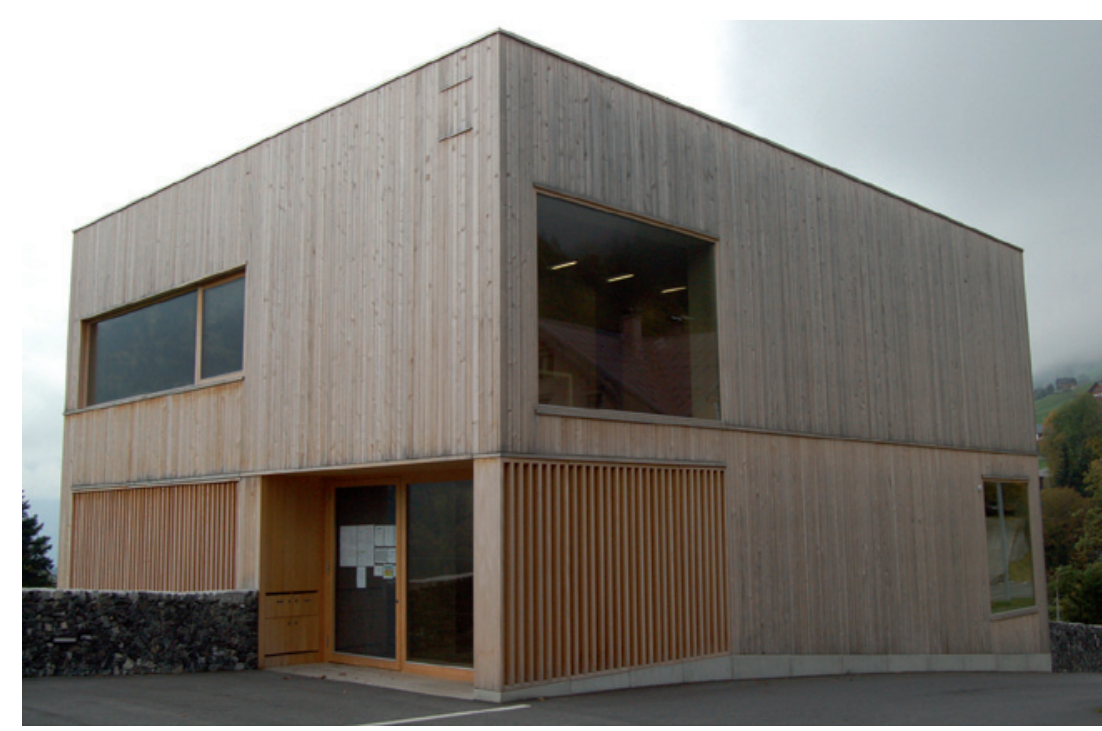

The municipal hall of St. Gerold in Großes Walsertal BR was constructed to passive-house standards. (C) BR Management

effectiveness of BRs can manifest itself in their success in developing sustainable solutions for using resources wisely, also in industrialized countries, and, in particular, in coping with global warming, which was identified as one of the most serious and globally significant challenges to society and ecosystems around the world today by UNESCO's MAB Programme (2008, p.6).

The six communities of Großes Walsertal BR take their role as living laboratories seriously. They defined their objective of achieving energy self-sufficiency within the mountain valley by 2020 , and even becoming an export region for renewable energy by 2030 . As plenty of timber grows in the mountain forests of the region, biomass (in form of wood chips) will be the main material used for heating. So far, biomass power plants already exist in Fontanella-Faschina and St. Gerold. Already there is enough biomass to cover $80 \%$ of the heating needs for communal buildings and $60 \%$ of the heating needs for private buildings. Besides optimizing the existing plants, the potential for introducing drinking-water power stations will be tested. The water containers and conduits already exist and only the surplus water would be used for generating electricity. In recognition of these efforts, the BR

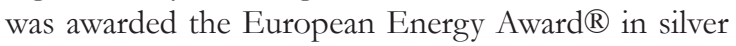
in 2010. The award is the highest recognition in Europe awarded to energy efficient communities (Lange 2011).

\section{Conclusions}

The four examples from India, Mexico, Ethiopia and Austria show that UNESCO's Network of Biosphere Reserves contributes to a sustainable development of mountain regions all over the world (although some of its members only exist on paper). The impact ranges from conservation to poverty reduction, to the development of effective measures, to combating climate change and reducing $\mathrm{CO}_{2}$ emissions in indus- 
trialized countries. Practice on the ground shows that the commonly required stakeholder involvement must not be seen as a temporary trend in protected areas development but as a key element for the success of long-term conservation efforts. It is crucial to include the knowledge of indigenous and other local people and to understand the people's concerns and issues in order to jointly identify opportunities for alternative income generating activities that do not deplete the natural resources in the long term. Wherever this is achieved, biosphere reserves can be effective tools to address the numerous challenges many mountain areas are or will be facing.

\section{References}

Bender-Kaphengst, S. 2011. Saving the Wild Coffee Forests. Joint Forces for Kafa Biosphere Reserve in Ethiopia. In: Austrian Academy of Sciences (eds.), Biosphere Reserves in the Mountains of the World. Excellence in the clouds? 89-92.

Bertzky, M. 2009. Mind the gap: Information gaps and bridging options in assessing in-situ conservation achievements. Dissertation. Ernst-Moritz-Arndt University Greifswald, Germany. Available at: http://ubed.ub.uni-greifswald.de/opus/volltexte/2009/575/ (accessed: 10/3/2011)

Biodiversity Hotspots 2007. Available at: http:// www.biodiversityhotspots.org/xp/hotspots/afromontane/Pages/default.aspx (accessed: 10/3/2011)

Borowski, D. \& C. Munteanu 2011. Biosphere Reserves in European Mountains: an Exploratory Survey. In: Austrian Academy of Sciences (eds.), Biosphere Reserves in the Mountains of the World. Excellence in the clouds? 35-40.

Bosak, K. 2008. Nature, Conflict and Biodiversity Conservation in the Nanda Devi Biosphere Reserve. Conservation and Society 6( 3): 211-224.

Dittrich, M. \& R.-P. Mack 2005. Biosphärenreservate in der Entwicklungszusammenarbeit. In: Deutsches MAB-Nationalkomitee (Hrsg.), Voller Leben. UNESCO-Biosphärenreservate - Modellregionen für eine Nachhaltige Entwicklung.

EFAP 1994. Ethiopian Forestry Action Program (EFAP). Ministry of Natural resources Development and Environmental Protection. Addis Ababa.

HDI 2010. Available at: http://hdr.undp.org/en/ media/HDR_2010_EN_Table1_reprint.pdf (accessed: 10/3/2011)

Lange, S. 2011. Increasing Energy Efficiency - the Case Study of Großes Walsertal Biosphere Reserve. In: Austrian Academy of Sciences (eds.), Biosphere Reserves in the Mountains of the World. Excellence in the clouds? 96-98.

International Energy Statistics for 2009. Available at http://www.eia.gov/cfapps/ipdbproject/iedindex3.cf m?tid $=90 \&$ pid $=45 \&$ aid $=8 \&$ cid $=\&$ syid $=2004 \&$ eyid $=$ 2009\&unit=MTCDPP (accessed: 1/3/2011)
Nune, S. 2011. Conserving Biodiversity for the Sake of Local People: Why Biosphere Reserves are Ideal Development Instruments for Ethiopia. In: Austrian Academy of Sciences (eds.), Biosphere Reserves in the Mountains of the World. Excellence in the clouds? 84-88.

Pedraza, R. 2011. Education and Training for Conservation: the Case of the Sierra Gorda Biosphere Reserve, Mexico. In: Austrian Academy of Sciences (eds.), Biosphere Reserves in the Mountains of the World. Excellence in the clouds? 100-102.

Progreso Network 2010. Available at: http:// www. sierragorda.net/Upload/Noticias / Archivos/20101004132833_systemSG3English.pdf (accessed: 28/2/2011)

Rodríguez-Rodríguez, D. \& B. Bomhard 2011. Towards Effective Conservation in Mountains: Protected Areas and Biosphere Reserves. In: Austrian Academy of Sciences (eds.), Biosphere Reserves in the Mountains of the World. Excellence in the clouds? 24-27.

Saxena, K.G., R.K. Maikhuri \& K.S. Rao 2011. Ecotourism in Nanda Devi Biosphere Reserve: A Win-Win Option for Environmental Conservation and Sustainable Livelihoods. In: Austrian Academy of Sciences (eds.), Biosphere Reserves in the Mountains of the World. Excellence in the clouds?: 77-80.

UNESCO, MAB (ed.) 2008. Madrid Action Plan for Biosphere Reserves (2008-2013). UNESCO 2011.Available at: http://www.unesco.org/new/en/ natural-sciences/environment/ecological-sciences/ biosphere-reserves/ (accessed on 10/2/2011)

\section{Author}

\section{Sigrun Lange}

holds a diploma degree in biology with a focus on tropical high-mountain ecosystems (University of Bayreuth, Germany), and an MSc degree in Protected Areas Management (University of Klagenfurt, Austria). For nearly 20 years she has worked now in biodiversity conservation and public relations, with field experiences in Papua New Guinea, Ecuador, Peru, Kenya, and Ethiopia. For the last seven years she has concentrated on protected areas management, especially biosphere reserves and cross-border cooperation in protected areas management. In 2008 she became CEO of E.C.O. Germany (Munich), a firm specializing in communication, management and planning processes in protected areas.

Dipl.-Biol. Sigrun Lange, MSc MPA, E.C.O. Germany GmbH, Eggernstr. 6, 81667 Munich, Germany Lange@e-c-o-deutschland.de

Results taken from the newly published volume: Austrian Academy of Sciences (ed.) 2011. Biosphere Reserves in the Mountains of the World. Excellence in the Clouds? Celebrating 40 years of UNESCO's MAB Programme: an Austrian contribution.

The publication is available from the Austrian Academy of Sciences Press (ÖAW-Verlag) 